Linguistik Terapan 17 (3) (2020): 281-290

Jurnal Linguistik Terapan Pascasarjana

Available online

http://jurnal.unimed.ac.id/2019/index.php/JLT-Unimed

\title{
SEMIOTIC IN MILK ADVERTISEMENTS
}

\author{
Roisa Monika Manurung \\ Aisyah Ginting \\ I Wayan Dirgayasa Tangkas
}

\author{
English Applied Linguistics Program \\ Postgraduate program-Universitas Negeri Medan
}

Diterima September 2020; Disetujui Oktober 2020; Dipublikasikan Desember 2020

\begin{abstract}
Television advertisement has a promotional function as a medium to advertise a product. It implicitly persuades people to create demand of a product that is being advertised. Implicit meaning can be studied with semiotic; it is the theory and study of sign, symbol, and signification as communicative behavior, especially as elements of language or other system of communication. This study is aimed to identify the types of signs of milk television advertisements. The writer focuses on four advertisements of milk products 'Bear Brand Sterilized advertisements, which published on television media since June 2009-2015. The methodology used in this research is qualitative method and the researcher uses semiotics approach of Charles Sanders Peirce. The data of this analysis are phrases, sentences, images, objects, and colors in each advertisement. The writer identifies some signs in each scene of the advertisement. The data are found in 25 in the bear brand advertisements. The result of this study shows that each scene contains signs such as icon,index, and symbol. There are 22 of icons, 8 indexes, and 26 symbols. In the analysis using Charles Sanders Pierce Triadic theory, the writer found that in every advertisement uses signs which consist of representament, object, and interpretant. The combination of the three signs will deliver the meaning of the selected object (advertisement) to the reader. The result of the study shows that the three kinds of signs are used to create clear meanings and both of them have a strong relationship in delivering messages of the products.
\end{abstract}

Keywords: Television Advertisement, Semiotic, Icon, Index, Symbol

How to Cite: Manurung, Roisa Monika (2020). Semiotics in Milk Advertisement. Jurnal Linguistik Terapan-Pascasarjana Unimed. 17 (3): 281-290.

ISSN: 2407 - 7410 


\section{INTRODUCTION}

One medium that can be used to convey wishes, intentions, and goals to others is advertising. Audiovisual ads can provide combination of moving sounds and images, therefore audiovisual advertisements can be enjoyed by anyone from children to adults. The combination of colors, sounds and movements in audiovisual advertisements make ads look more real and has power to deliver and strong influence, it also makes the consumers become easy to understand the product that advertised without having the ability to read, and can give a deeper impression to consumers so that consumers more quickly remember the advertised product (Rangkuti, 2002:187190).

Generally audiovisual advertisements that are broadcast on mass media have a short duration of time. In the short duration of time there are many messages from a product that the advertiser wants to convey. Therefore, advertiser uses a variety of signs so that messages from a product can be conveyed properly. The use of various kinds of signs also aims to attract attention and the interest of potential customers. These signs can icon, index and symbol. Various kinds of these marks were studied using the semiotic approach. In semiotics, advertisements can be observed and made based on a significant relationship (signs, object, interpretant). There are various interesting television commercials in Indonesia; one of them is the Bear Brand milk television commercial. The ad that is classified as Above the Line (ATL) tells about milk, which is known for its purity. However, Bear Brand television commercial is unique in its design, namely disunity, in the television advertisement there is a white dragon which is not included in the packaging. The existence of disunity in Bear Brand makes his visual identity unclear. Besides that, the interpretation of the use of animal characters becomes a problem. Because there are problems in the use of visual identity, it makes the delivery of messages in advertisements very abstract .This research concentrates on analyzing the three types of signs found in four Bear Brand advertisements, as well as the relationship between them

\section{A. Model Semiotic of Charles Sander Peirce}

Charles Sanders Peirce named the sign a representamen, in order to express the fact that a sign is something that "represents" something else in order to suggest it (that is, "represent" it) in some way Danesi (2007). According to Saussure, semiosis system is based on signifier and signified whereas Peirce explains this system with a three-element integral: representamen, interpretant, and 
object. Among these three connections, representamen is a sign; an interpretant is associations or a person that creates connection between the sign and object; and object symbolizes the sign (Kucukerdogan, 2011:160).

Charles Sanders Peirce explained that there are three kinds of signs: icons, indexes, and symbols. Icons signify by resemblance, indexes signify by cause and effect, and symbols signify on the basis of convention. Therefore, a photograph would be iconic (it signifies by resemblance), smoke coming out of a house would be indexical for fire (it signifies by cause and effect) and flags would be symbolic (one must learn what flags signify). The term iconic now has another meaning and is used loosely to refer to people, places, objects, and so on.

\section{B. Interpreting the Signs}

In linguistics, the nature of the signified has led to discussions which have centred chiefy on its degree of reality'. However many people agree on the fact that the signified is not 'a thing' but a mental representation of the thing' (Barthes, 1964:133).

The signified is one of the two terms of the sign; the only difference which opposes it to the signified is that the latter is a mediator. The situation could not be essentially different in semiology, where objects, images, gestures, etc., in as much as they are significant, refer back to something which can be emphasized only through them, except that the semiological signified can be taken up by the linguistic signs. For instance, that a certain sweater means long autumn walks in the woods; here the signified is mediated not only by its testamentary signifier (the sweater), but also by a fragment of speech (which greatly helps in handling it (Barthes, 1964:133)

The nature of signifier cannot be separated from that the signified. The only difference is that the magnifier is a mediator: some matter is necessary to it. In semiology, where people should have to deal with mixed systems in which different kinds of matter are involved (sound and image, object and writing, words etc.), it may be appropriate to collect together all the signs, in as much as they are home by one and the same matter, under the concept of the typical sign: the verbal sign, the graphic sign, the iconic sign, the gestural sign are all typical signs (Barthes, 1964:133). In semiotics, this creates different substances -sound, image, object and writing, etc. Mixed composition that people face, it would be appropriate to gather all signs by the same and only substances as they have been presented, under the notion of varietal sign: lexical literary, iconic, behavior sign form a single varietal sign.(Barthes 1977:41). 


\section{Television Advertisement}

Advertisement becomes a great phenomenon in this era regarding their roles as tools in sharing information of what they are advertised. Commercial advertisements are advertisements used to sell products. It should offer information, stress buyer's benefit and build a good brand reputation. Commercial advertisements published on TV try to intrigue the viewers to see the entire commercial. To achieve this goal, the copy writers have to create advertisements in such a creative way so that the viewer's feel that they need to see the advertisement.

Advertisement motivates people by appealing to their problem, problems and goals by offering a means of solving their problem, satisfying their desires and achieving their goals. To the individual consumer, a product is not so much a physical object as a bundle of satisfaction. Automobiles provide transportation, but also status and social and job mobility. Clothing is worn to impress others, to make statement about the wearer, and to keep warm. The life-giving spark of an advertisement is its promise of the special significant benefit the product will provide a promise the product must be able to fulfill. That special significant benefit becomes the appeal of an advertisement. An appeal is a statement designed to headline or slogan.

Advertisement is also a product promotion. It has some texts, which provides information about the product, and more important provides anchorage for the image. Under the general category of text, there may be descriptive information about the product, other text that serves the purpose of catching the reader s (viewers) attention, as well as short phrases that act as a kind of slogan and finally the name of the company and / or the name of the product.

Furthermore, the most important purpose of advertisement is to deliver message or information to an audience for one reason or another, in order to influence and persuade them to believe or get interested in what is being advertised or offered. Thus, in order to accomplish the purpose, the language of advertisement should be simple, well arranged, effective, and communicative, so that the advertisements are easy to be understood Wells \& Moriarty (2000).

\section{Advertisement as the Semiotics Signification}

Advertisement as the language communication has a specific language structure. It expresses the message with the certain language and sometimes contain of false expression than the real purpose of the advertisement. According to the semiotic signification, advertisement has contain more than a signs, it consist of the language element which arranged from a signifier or the material element of the advertisement showed as picture, photo and illustration and a concept 
of signified and the meaning beyond it signifier. This structural element of advertisement is used to show a reality or even falsifying the reality of the advertisement.

Usually, an advertisement has three elements of sign. An object of the product that advertises, contexts of advertisement around it object showed as the thing that gives the context of and object. The text of advertisement is in written language. Beside it elements, advertisement has a levels of meanings, it a denotative meaning, and a deeper meaning or connotative meaning when the advertisement related to the cultural context and the understanding of an ideology.

Beside it elements, advertising has indicate to a certain codes. The first code that exists in usual texts is a linguistic code refers to what the texts expressed. Generally, this code is express about what is in the meaning of dictionary or in linguistic order.

Barthes (1977), a well-known as the scientist who practiced linguistic and semiology model of Saussurean and Piercian to analyze the secondary code in cultural product such advertisements. In his book $\mathrm{S} / \mathrm{Z}$ proposed another term to understand the sign by arranging and grouping codes into five, there are a hermeneutic code, semantic code, symbolic code, narrative/proairetic code and cultural code.

Before he defines a sign into five codes above, he made two order of signification of meaning to get a meaning in level of connotation and related to cultural condition. In this order of signification, Barthes interrogate every pieces of cultural and material product such advertisements and explained that advertisements contribute to cultural myths as second-order signs.

The first order is based from Saussure work on semiology. In this first order shows a relation between signifier and signified in sign and between a sign with other reference in external reality. Roland Barthes called this order with denotation. A meaning in denotation level may show a similarity except in connotation level. In this case, denotation tends to be described as the definitional, literal, obvious or commonsense meaning of a sign.

The term of connotation is used to refer to the socio cultural and association to ideological of the sign. These are typically related to the interpreter's class, gender, and so on. Sign according to Barthes are more polysemy in their connotations than their denotations.

1. These are definition of codes that Barthes proposed in his second order of signification: A hermeneutic code consists of all units which function is to articulated in various ways question, its response, and the variety of chance events which can either 
formulate the question or delay its answer, or even, constitute an enigma and lead to its solution.

2. A Semantic code is a code of connotation which utilizes hints or flicker of meaning generated of certain signifiers. Third is symbolic code which code of recognizable groupings or configuration regularly repeated in various modes and by various mean in the text, which ultimately generates the dominant figure in the carpet.

3. Other code is a narrative/proairetic code. Narrative or proaretic code is a code of action derived from the concept of proaresis, the ability rationally is to determine the result of an action, and this code is also embodied in sequence such as lexica.

4. The last code which Barthes called as cultural code, which code manifest as a gnomic, collective, anonymous and an authoritative voice which speaks for and about what it aims to establish as accepted knowledge or wisdom.

\section{METHODOLOGY}

This research used a descriptive qualitative method. A qualitative research itself emphasizes more on qualities rather than entities (Bogdan \& Biklen, 2007. According to Lincoln and Guba (1982:128-152) In qualitative research, instrument of qualitative research is the researcher's itself. The data of the study are verbal text (phrase and sentence) and visual text (picture, sounds, color) in four audio-visual ads of Bear Brand which published on television from 2009-2015. In collecting the data, the researcher used four steps. Firstly, the researcher downloaded the advertisements of Bear Brand Ads from a site namely YouTube. Secondly, the researcher divided each advertisement into some scenes. Thirdly, the researcher identified each seen from the seen word, heard word, picture, object, and color, and classified each data into icon, index, and symbol. And the last, the researcher investigates the meaning of signs used in BB ads. The data analysis is process systematically, transcript, field's notes, and other materials that the writer accumulate to increase the understanding of them and to enable the writer to present what he has discovered to other (Bogdan and Biklen: 1982). The technique of the data analysis was applied based on interactive models technique by Miles, Huberman and Saldana theory (2014:161), 


\section{FINDINGS AND DISCUSSION}

There are fifty-six semiotic signs that occurred in four milk advertisements. Television milk advertisement used signs in delivering meaning of the advertisements. The sign of television advertisement consist of signifier and signified. Each signs are represented implicitly. The signs consist of three types of sign based on Piece theory namely: icon, index, and symbol.

The signs which are categorized as icon found BB Ads in 2009
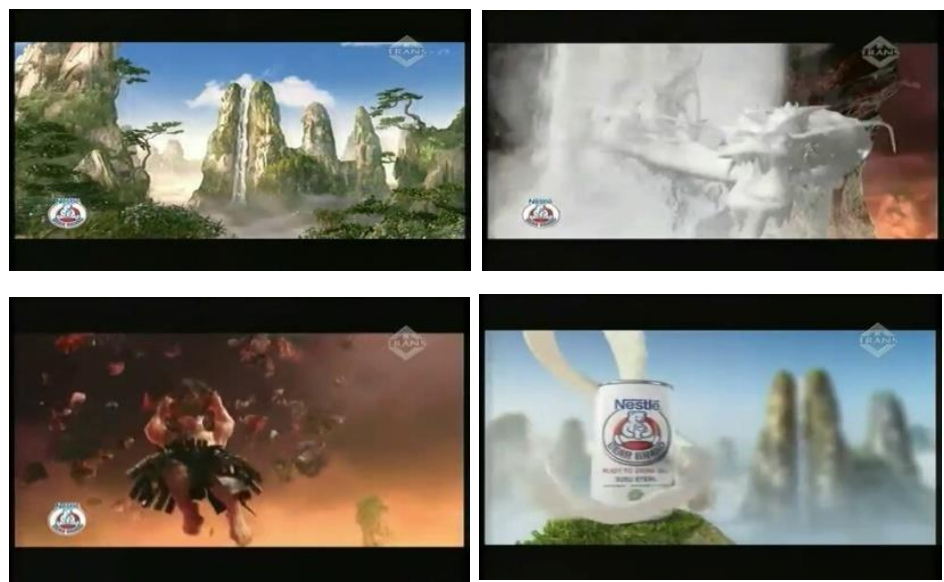

The objects of each scene are Mountain and Frog the white dragon, the stone, the writing of 'Rasakan

kemurnianya!, each signs categorizes as icon.

The interpretant

The icon which found from the scene is mountain that describe natural condition, where in it there are cliffs, waterfall that flows from a high cliff, the splashing of water, white clouds, the chirping of birds, and the mountains surrounded by trees) all of it creates a peaceful impression. The fog is also classified into a sign that is an icon. The fog is formed due to the cold, which indicates a fresh morning situation around the mountain. The white dragon that appears from inside the waterfall is an icon, the white dragon is an icon of strength. Stone that used by monster to attack dragons is an icon, this stone is broken cliffs that has destructed by monster and used back to attack the dragon. The purity of milk describe in the icon of dragon which has white color and strong.

The signs which are categorized as index found BB Ads in 2009. 


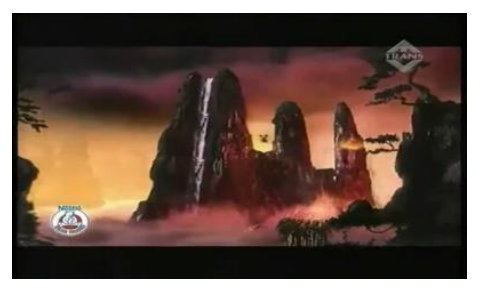

The red color becomes the sign of this scene, it categorized as index

The interpretant

The calm impression that first appeared in this ads changed immediately, the appearance of red monsterchanged the atmosphere around the mountain become reddish where usually often associated with energy, war, danger, strength,strong determination, passion, and love, in this ad, the appearance of red is a sign of a danger.

The signs which are categorized as symbol found BB Ads in 2009
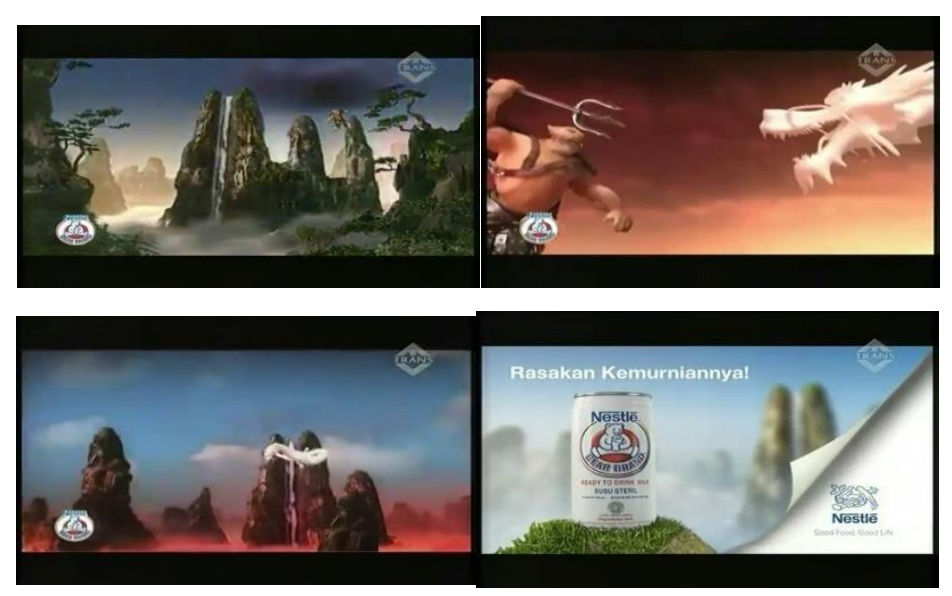

Signs found in four scenes and categorized as symbols

1. Monster

2. Black Clouds

3. Psychology logo 'Trisula'

4. The blue sky

5. Logo type of Bear Brand

6. Logo type of Nestle

Interpretant

Monster is usually used for object whose existence is still doubtful, in this advertisement,the appearance of the monster is a sign of chaos. Black clouds that appear when the arrival of monsters 
are a sign of danger, which will affect the natural conditions around the mountains. Trisula commonly used as the principal symbols in Hinduism and Buddhism. In India and Thailand, the term also often refers to a short-handled weapon which may be mounted on a staff. In this advertisement, monsters use the Trisula to attack the white dragon. The color of the sky returned to blue when the white dragon defeated the red monster, the color change from red to be blue, indicating the natural atmosphere was calm again. The color of the sky returned to blue when the white dragon defeated the red monster, the color change from red to be blue, indicating the natural atmosphere was calm again. Logotype of Nestle is a symbol of Nestle Company that has been agreed.

\section{CONCLUSION}

It can be concluded that all of the advertisements use semiotic signs. They are 20 icons, 8 indexes, and 26 symbols. The signs are used to make them interesting, understandable, and effective. The signs are always added of Bear Brand advertisements in order to deliver the clearest message about the supposed benefits of the products advertised. The signs are always attached in all advertisements. Their appearances were meant to make the advertisements clear for the audience. The sign which comes from word seen and wood head plays a strong role in persuading the audience to pay attention on the product that is being advertised or sold. The sign which comes from pictures and colors is also crucial. Some people like to see something visually rather than verbally. The role of the sign in an advertisement is extremely important in convincing the audience to buy the product that is being advertised. The relationship between each sign is tight. Both of them always support each other in delivering the messages of each of the products advertised. The function of sign which come from word seen and word heard sign is not clear enough without the help of a sign in the form of picture object and color while the verbal sign adds credibility to the visual. Both signs rely on each other in creating a clear meaning of a certain product that is being advertised. Therefore, when the signs are attached in one advertisement, the message of an advertisement can be achieved.

\section{REFERENCES}

Barthes, R., 1977. Elements of semiology. Issue no:1 A. Lavers \& C. Smith (translation), London: Jonathan Cape. 
Bogdan, R.C and S.K Biglen. 1982. Qualitative Research in Education: an Introduction to Theory and Method. Bostom : Allyn \&Bacon.

Chandler, D. (2007). Semiotics: The Basics (Second Edition). London and New. Denzin, N. K., \&

Lincoln, Y. S. (Eds.) (2011). The SAGE Handbook of Qualitative Research (5 ${ }^{\text {th }}$ Ed.). Thousand Oaks, CA: SAGE Publications.

Danesi, M., (2007). The Quest for Meaning: a Guide to Semiotic Theory and Practice. Toronto: Press University of Toronto.

Guba EG, Lincoln YS. (1982) The Evaluator as Instrument. In: Guba EG, Lincoln YS, editors. Effective Evaluation. San Francisco, CA: Jossey-Bass.

Küçükerdoğan, R. (2009). Reklam Nasıl Çözümlenir?, Issue no:1. İstanbul: Beta Yayınları

Miles, M., M Huberman, J. Saldana. (2014). Qualitative Data Analysis, A Methods Sourcebook. Amerika: Arizona State University.

Rangkuti, Freddy. (2002). Creating Effective Marketing Plan: Teknik Membuat Marketing Plan Berdasarkan Customer Values \& Analisis Kasus. Jakarta: Gramedia Pustaka Utama.

Wells, W.B, Jhon \& Moriarty, Sandra. (2000). Advertising Principles \& Practice; Fifth Edition. 